\title{
Food and Feeding Ecology of Emperor Penguins in the Eastern Weddell Sea
}

\author{
Norbert Klages \\ Port Elizabeth Museum, P.O. Box 13147, Humewood 6013, Port Elizabeth, South Africa
}

Received 5 October 1987; accepted 11 October 1988

Summary. The diet of the emperor penguin Aptenodytes forsteri in the eastern Weddell Sea, Antarctica was studied during October and November 1986 by stomach content analysis. Emperor penguins fed mainly on Antarctic krill Euphausia superba, Antarctic silverfish Pleuragramma antarcticum and squid Psychroteuthis glacialis. Benthic prey was not found. The prey composition suggests two different feeding strategies, shallow dives exploring the rugged underside of sea ice where krill is taken, and deep dives when mesopelagic fish and squid are consumed. Chicks were fed on average every 1.44 days.

\section{Introduction}

Emperor penguins Aptenodytes forsteri have long been regarded as important warm-blooded predators in the pelagic ecosystem of the high Antarctic. Until recently, however, only anecdotal data on their consumption of fish, cephalopods and crustacea were available (Levick 1914; Murphy 1936; Stonehouse 1953, 1967; Prevost and Sapin-Jaloustre 1965). Offredo et al. (1985) and Offredo and Ridoux (1986) recently published the first quantitative study of the penguins' diet during the chick-rearing period based on samples taken at Pointe Géologie, Adélie Land, one of the more accessible rookeries in Antarctica. Green's (1986) note on the analysis of faecal samples from the edge of the sea ice off the Vestvold Hills, Prydz Bay, remains the only information on their diet away from colonies.

During the Winter Weddell Sea Project 1986 (WWSP) with $R V$ Polarstern, West Germany established a field station near a large breeding colony of emperor penguins at $72^{\circ} 52^{\prime} \mathrm{S} 19^{\circ} 25^{\prime} \mathrm{W}$ in the Drescher Inlet on the Vestkapp Ice Shelf, Antarctica. This allowed a comprehensive investigation of the food and feeding ecology of this penguin in a previously unsampled region. The study aimed to examinate the diet composition during the chick-rearing period, the sizes of prey consumed, the av- erage duration of foraging trips by adults and to estimate the daily total food consumption of the chicks.

\section{Materials and Methods}

Study Site

Size and structure of the breeding colony in the Drescher Inlet are described elsewhere (Klages and Gerdes 1988). This funnel shaped inlet has a width at the mouth of about $6 \mathrm{~km}$ and then narrows to less than $1 \mathrm{~km}$; its length is about $20 \mathrm{~km}$.

Oceanographic conditions off the Drescher Inlet are characterized by water temperatures below $0{ }^{\circ} \mathrm{C}$ throughout the year and a variable extent of sea ice. Whereas the central parts of the Weddell Sea are almost permanently covered by ice, large stretches of the coastal region become, at times, ice free. Under the influence of surface Ekman transport of the Antarctic coastal current which enters the Weddell Sea from the east, and induced by persistent katabatic winds from the continent, forming ice is driven offshore and a polynya opens along the eastern and southern shelf ice edge. At the mouth of the Drescher Inlet water depth exceeds $400 \mathrm{~m}$, increasing rapidly to depths of several thousand $\mathrm{m}$ further offshore. During the observation period, from 20 October to 23 November 1986, daylight was continuous.

\section{Methods in the Field}

Sampling was conducted from 28 October to 20 November 1986 . Thirtyfour adult birds returning from foraging trips were caught approximately one $\mathrm{km}$ from the edge of the fast sea ice, restrained and transferred by sledge to a field camp where the bird's stomachs were lavaged using a water-offloading technique (Wilson 1984). Up to 101 of fresh water at approximately $30^{\circ} \mathrm{C}$ were administered by a tube into the stomach until the penguin began to regurgitate. It was then turned upside down towards the collecting bucket while firm pressure against its abdomen and opening of the beak by hand assisted in collection of the stomach contents. Samples were drained through a sieve of $1 \mathrm{~mm}$ mesh size and stored frozen for later analysis. Birds were usually treated twice, occasionally three times, in order to flush out the entire stomach contents.

In two cases the treatment had to be abandoned prematurely because the birds showed obvious signs of great stress; consequently these samples remained incomplete. Two other stomachs were empty except for highly digested squid beaks from previous meals.

Prior to their release the birds were weighed using a scale suspended under a tripod.

The average duration of adult foraging trips was determined on 16 and 17 November. Movements of all foraging adults, to and from the 
colony, could be monitored with binoculars from an observation post at the edge of the shelf ice overlooking the entire entrance of the inlet. Fifteen-minute counts at hourly intervals, over a total of $27 \mathrm{~h}$, of departing and returning penguins allowed estimation of the average time an adult spent at sea gathering food, and to check for any diurnal rhythm in their arrival and departure patterns.

\section{Methods in the Laboratory}

After weighing, the drained diet samples were sorted. Subsamples were taken only in few instances when the sample volumes were very large. Repeated washings and swirling in a plastic bowl separated the highly digested unidentifiable material from the less digested material and loose hard-part remains. The generally advanced state of digestion of prey in the stomachs meant identification of prey items was almost exclusively based on analysis of fish otoliths, squid lower beaks and crustacean exoskeletons.

All loose otoliths and those removed from fish skulls were cleaned, dried and counted. Otolith diameter (OD) was measured for all otoliths that showed no or only minor signs of attrition using a binocular microscope fitted with a graticule. Identification of otoliths was made by direct comparison with material held in the reference collection of the Port Elizabeth Museum, and from the literature (Hecht 1987). Total length (TL) or standard length (SL) and mass (W) of fish was estimated from regresśions linking OD to these parameters (Hecht 1987; Plötz 1986).

Cephalopod mandibles (squid beaks) were collected loose from the diet samples or removed from the buccal mass when squids were only partially digested. The number of squids ingested was determined from the count of the number of lower beaks. Guided by experience gained in similar studies (Adams and Klages 1987; Adams and Klages, in press; Brown and Klages 1987) highly digested beaks were excluded from the counts as they originate from previous meals. Beaks were identified to the lowest possible taxon by comparison with material held in the reference collection of the Port Elizabeth Museum and from the literature (Filipova 1972; Clarke 1986). Lower rostral length (LRL) (Clarke 1962) was measured with Vernier calipers or under a microscope. Regressions were used to estimate dorsal mantle length (DML) and mass (W) of the cephalopods from LRL (Clarke 1986; Offredo et al. 1985; Nemoto et al. 1985 )

Crustaceans were identified using published keys (Bowman and Gruner 1973; Kirkwood 1982). Total mass of krill in each sample was obtained by weighing. The advanced stage of digestion and abundance of euphausiids (Euphausia superba) in the diet samples precluded counting and measuring of all individual krill. Hence mean total length was calculated from measurements of well preserved specimens arbitrarily selected from 18 diet samples. Mass was calculated from the regression provided by Kils (1981), and the calculated value of mean mass was used to assess their numerical abundance in the diet. Amphipods were weighed directly.

The composition of the diet was investigated by mass, numbers and frequency of occurrence as recommended by Hyslop (1980) and Duffy and Jackson (1986).

\section{Results}

\section{Meal Size and General Composition of the Diet}

Mean mass of food samples obtained from adults was $1335 \mathrm{~g}$ ( $\mathrm{SD}=1031, N=30$ ), ranging from $169 \mathrm{~g}$ to $3590 \mathrm{~g}$. Adult body mass varied from $22.1 \mathrm{~kg}$ to $37.0 \mathrm{~kg}$ (mean $28.1 \mathrm{~kg}, N=32$ ) after removal of the stomach contents.

Twelve prey species were identified in the diet (Table 1). These included five species of fish, three species of squids, and four species of crustaceans. Three beaks of a further cephalopod species (Gonatus antarcticus, Gonatidae) were found in one of the two incomplete diet
Table 1. Numbers and percent frequency of occurrence of prey items identified from emperor penguin diet samples $(N=30)$

\begin{tabular}{lrr}
\hline Prey item & Numbers $\%$ frequency \\
\hline Fish & 278 & 53.3 \\
Pleuragramma antarcticum, & & \\
Nototheniidae & 128 & 36.7 \\
Notolepis coatsi, Paralepididae & 7 & 13.3 \\
Trematomus ?lepidorhinus, & & \\
Nototheniidae & 3 & 10.0 \\
Pagetopsis maculatus, Channichtyidae & 2 & 6.7 \\
Chionodraco sp., Channichtyidae & 1 & 3.3 \\
Unidentified fish & & \\
Squid & 643 & 66.7 \\
Psychroteuthis glacialis, & 63 & 56.7 \\
Psychroteuthidae & 2 & 6.7 \\
Alluroteuthis antarcticus, Neoteuthidae & & \\
Galiteuthis glacialis, Cranchiidae & 60051 & 90.0 \\
Crustacea & 17 & 20.0 \\
Euphausia superba, Euphausiacea & 7 & 13.3 \\
Hyperiella sp., Amphipoda & 1 & 3.3 \\
Cyllopus sp., Amphipoda & 61203 & \\
Themisto gaudichaudii, Amphipoda & & \\
Total &
\end{tabular}

samples that were subsequently excluded from the detailed analysis.

Crustacea were present in $93.3 \%$ of the samples, squid in $80.0 \%$ and fish in $73.3 \%$. Overall, crustaceans comprised $52.1 \%$ of the diet by mass and featured even more prominently in the numerical analysis $(80.3 \%)$ due to their small individual body size. Percent diet composition by mass and numbers of main prey groups is summarized in Table 2.

The samples formed three distinct groups according to the main prey types present. In 13 of the 30 samples the crustacean component was $>\mathbf{7 4 . 7 \%}$ by mass; in another 10 samples the joint fish and squid component was $>79.7 \%$, whereas only seven samples revealed no marked dominance of a certain prey type (Fig. 1).

Most diet samples contained stones. These ranged from 15.8 to $5.0 \mathrm{~mm}$ in diameter (mean $=9.43, \mathrm{SD}=$ 2.82, N=30) and consisted chiefly of igneous rocks (granite, basalt).

Table 2. Percent diet composition by mass and numbers of main prey classes consumed by emperor penguins

\begin{tabular}{lccc}
\hline & Fish & Squid & Crustacea \\
\hline Mass (\%) & & & \\
Mean & 38.1 & 9.8 & 52.1 \\
SD & 40.5 & 12.0 & 38.6 \\
Range & $0-99.8$ & $0-42.8$ & $0-100$ \\
Numbers (\%) & & & \\
Mean & 16.8 & 3.3 & 80.3 \\
SD & 30.9 & 6.6 & 34.4 \\
Range & $0-91.7$ & $0-35.0$ & $0-100$ \\
\hline
\end{tabular}




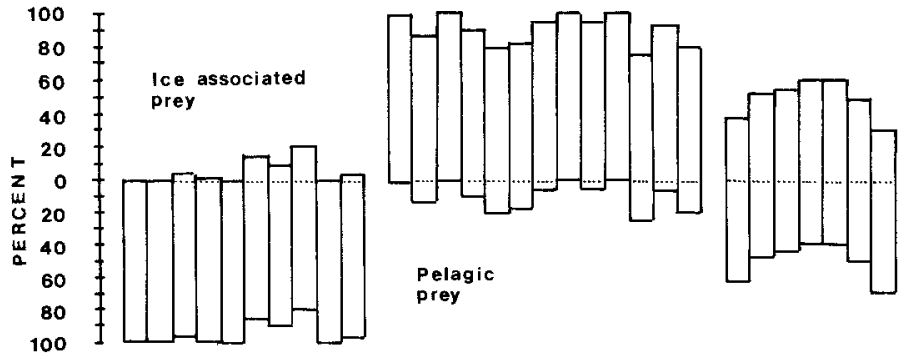

Fig. 1. Proportions of ice associated prey (krill) and pelagic prey (fish and squid) consumed by emperor penguins ( 30 samples)

\section{Fish}

The Antarctic silverfish Pleuragramma antarcticum was the most abundant species $(66.3 \%)$. The paralepidid Notolepis coatsi was also numerically important (30.5\%), whereas the remaining species Pagetopsis maculatus, Chionodraco sp. and Trematomus ?lepidorhinus comprised less than $3 \%$. One pair of fish otoliths remained unidentified.

Abundances of the two main fish species varied temporally. In October only 4 Notolepis coatsi were recovered from a total of 12 samples. This increased to 124 specimens in November (18 samples). Conversely, 188 Pleuragramma antarcticum were recovered in October and 90 in November.

Mean size of $P$. antarcticum consumed was $146.9 \mathrm{~mm}$ SL (24.6 g). However, the size class distribution was bimodal with one peak at $99.0 \mathrm{~mm}$ SL (6.7 g) and a second at $166.8 \mathrm{~mm}$ SL (37.3 g) (Fig. 2). Standard parameters of prey sizes for all fish consumed are given in Table 3.

\section{Squid}

The squid Psychroteuthis glacialis was the most numerous cephalopod in the diet $(90.8 \%)$. The other two squid species, Alluroteuthis antarcticus and Galiteuthis

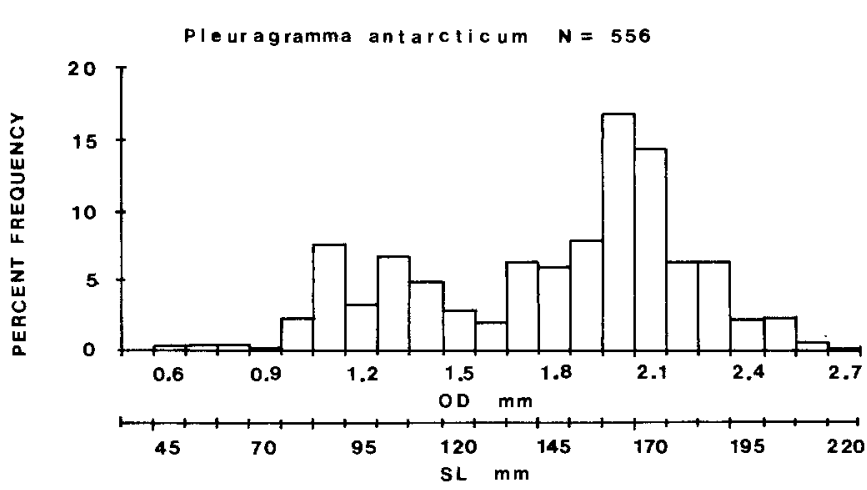

Fig. 2. Prey sizes of Pleuragramma antarcticum consumed by emperor penguins. $\mathrm{OD}=$ otolith diameter, $\mathrm{SL}=$ standard length

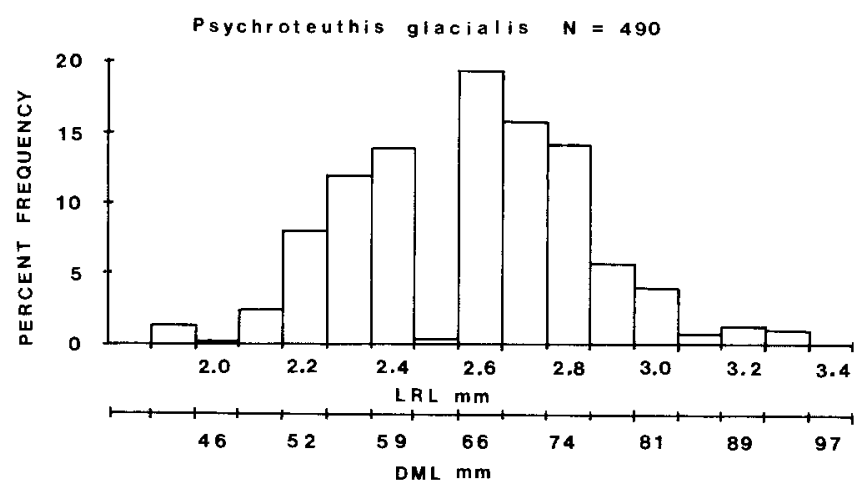

Fig. 3. Prey sizes of Psychroteuthis glacialis consumed by emperor penguins. $\mathbf{L R L}=$ lower rostral length, $\mathrm{DML}=$ dorsal mantle length

glacialis comprised only $8.9 \%$ and $0.3 \%$, respectively. $P$. glacialis of $66.2 \mathrm{~mm}$ DML $(6.6 \mathrm{~g})$ was the most frequently takes size class (Fig. 3). Standard parameters of prey sizes for all squid consumed are given in Table 3.

\section{Crustacea}

Antarctic krill Euphausia superba was the most important prey item in the diet samples in terms of numbers,

Table 3. Summary of otolith diameter (OD), lower rostral length (LRL), estimated length and mass of fish and squid recovered from emperor penguin diet samples. Fish length is given as standard length (SL) or total length (TL indicated with * next to species name), squid length is given as dorsal mantle length (DML). The table remains incomplete for some prey because appropriate regressions are not available

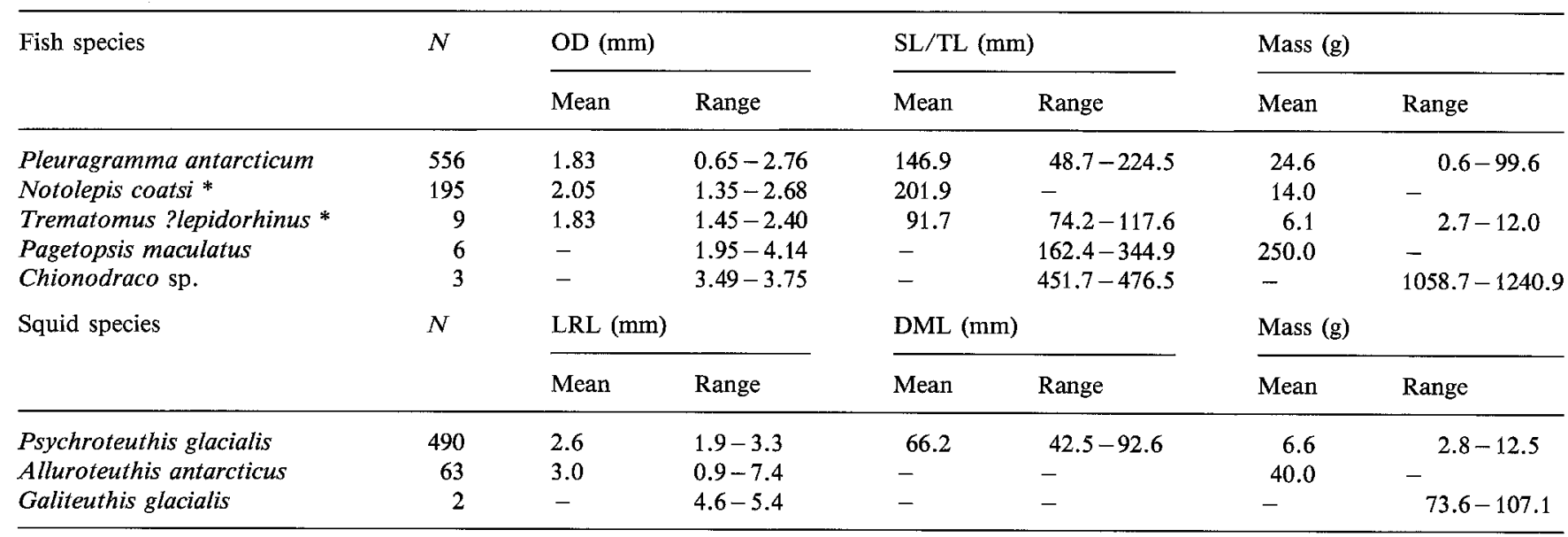


mass and frequency of occurrence (Tables 1 and 2). The mean length of individuals taken was $38.5 \mathrm{~mm}$ TL $(\mathrm{SD}=5.2 \mathrm{~mm}, N=84$ ) corresponding to a mass of $0.39 \mathrm{~g}$.

Amphipods were rare, making up only $0.04 \%$ of this prey class by numbers.

\section{Mean Duration of Foraging Trips and Amount of Food Delivered to the Chicks}

Arrival and departure patterns of adults at the colony showed no marked diurnal rhythm (Fig. 4). Means of the number of leaving and arriving penguins per $15 \mathrm{~min}$ (mean in $=50.7, \mathrm{SD}=12.1$; mean out $=46.0, \mathrm{SD}=9.1$ ) were not significantly different $(t$-test, $P<0.05)$ indicating that the colony at this time was neither increasing nor decreasing in numbers. As both means were not significantly different, the results of arrival and departure counts were pooled. The combined data yielded a mean exchange rate of $(50.7+46.0) / 2=48.35$ penguins per $15 \mathrm{~min}$. This figure served to estimate that $48.35 \times 4 \times$ $24=4642$ penguins arrived at the colony per day delivering food to their chicks.

We counted 6660 chicks at the Drescher breeding colony at this time and numbers of adults corresponded well with this figure, consistent with one adult per pair remaining with their offspring while the partner was feeding at sea (Klages and Gerdes 1988). Hence mean feeding interval was $6660 / 4642=1.435$ days $(34 \mathrm{~h} 26 \mathrm{~min}$ ). Because both sexes participated in chick-rearing maximum foraging time per adult was therefore $2 \times 1.435=2.87$ days $(68.88 \mathrm{~h})$.

Assuming that the entire stomach contents (mean $1335 \mathrm{~g}$ ) of adult penguins returning to the colony was fed to chicks (i.e. adults satisfy their own demands while out at sea), mean mass of food delivered to a chick per day per adult was $1335 / 1.435=930.3 \mathrm{~g}$, resulting in $(930.3 \times 6660) / 1000=6196 \mathrm{~kg}$ food intake of all chicks in the colony per day. This amount was composed of $2361 \mathrm{~kg}$ fish, $607 \mathrm{~kg}$ squid and $3228 \mathrm{~kg}$ krill.

\section{Discussion}

\section{Diet}

The study of Offredo and Ridoux (1986) portrays the emperor penguin in Adélie Land as a largely ichthyophagous predator ( $65 \%$ by number, $95 \%$ by mass), feeding extensively on small nototheniids. The few fish they succeeded in identifying to species level belonged to Gymnodraco acuticeps and Pagothenia (Trematomus) borchgrevinki, a shoaling species associated with the underside of the ice.

Although fish were also a major food source in the present study, different species were important. The nototheniid Pleuragramma antarcticum is a pelagic circum-Antarctic fish species living from surface waters down to more than $700 \mathrm{~m}$ depth. In the Weddell Sea highest concentrations were generally found over the continental slope and inner-shelf depressions at water depths

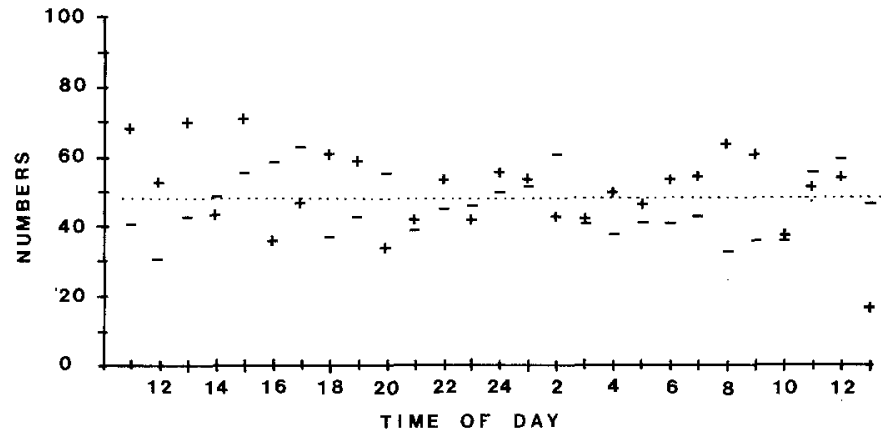

Fig. 4. Numbers of arriving (+) and departing ( - ) emperor penguins per $15 \mathrm{~min}$ at the breeding colony in the Drescher Inlet. Dotted line $=$ mean exchange rate ( 54 observations)

below $200 \mathrm{~m}$, making up $44-90 \%$ by numbers of all fish caught in trawls (Hubold 1984, 1985). Green (1986) also identified this species as a major prey in his analysis of emperor penguin excreta.

Of particular interest is the dominance of $P$. antarcticum in the diet of another co-occurring and abundant top predator in the shelf system of the Antarctic, the Weddell seal Leptonychotes weddelli. Plötz (1986) reported $P$. antarcticum as the most numerous fish species in its diet $(61.1 \%$ and $93.8 \%$ in diet samples from 1983 and 1985 , respectively). Prey sizes of $P$. antarcticum consumed by emperor penguins and Weddell seals are nearly identical (166.8 mm SL (second peak Fig. 2) versus $155 \mathrm{~mm}$ SL for his eastern samples). Fingerlings ( $99 \mathrm{~mm}$ SL, first peak Fig. 2) which occur at higher densities in upper water layers (Hubold 1984) are under-represented in the stomachs of the seals consistent with their superior diving capability (Kooyman 1981) and presumed preference for larger (and more rewarding) prey. Another important difference between their diets is the absence of benthic prey in emperor penguins.

The swift-swimming paralepidid Notolepsis coatsi is commonly taken as a by-catch in pelagic trawls and krill fisheries (Fischer and Hureau 1985). In the eastern Weddell Sea they are regarded as typical components of the offshore oceanic ecosystem and occur only close to the ice barrier where relatively warm bottom water approaches the coast (Hubold 1984). The sudden increase of this species in the diet samples during November is probably due to such a change in the oceanographic regime.

Off the Drescher Inlet water depth exceeds by some $150 \mathrm{~m}$ the deepest recorded dive of an emperor penguin (Kooyman et al. 1971), and the seabed is the only possible source of the pebbles retrieved from the stomach contents. This suggests that emperor penguins do dive occasionally to great depths where they may consume fish with more demerso-pelagic habits such as Trematomus sp., Chionodraco sp. and Pagetopsis maculatus.

The Antarctic squids Alluroteuthis antarcticus and Galiteuthis glacialis are both known to live in the mesopelagic zone of the Weddell Sea sometimes rising to the surface layers (Rodhouse and Clarke 1986; Okutani and Clarke 1985). 
Judging by its predominance in the samples Psychroteuthis glacialis appears to be the most numerous squid species in the shelf waters. Prey sizes reported by Offredo et al. (1985) include larger animals, and their percent-frequency distribution peaks at different beak sizes $(1.0-2.0$ and $4.0-7.5 \mathrm{~mm}$ LRL versus $2.6 \mathrm{~mm}$ LRL in this study; Fig. 3). This difference is explained by the time of year in which the collections were made. Offredo et al. (1985) collected all beaks in the large group before October. Therefore, their samples include the last of the mature squids engaged in spawning prior to death. Beak sizes recovered during this study represent the immatures hatched in the previous year.

Although euphausiids contributed only $2 \%$ by mass in the study performed by Offredo and Ridoux (1986), seven of their samples (or $21.4 \%$ ) contained $96 \%$ of all Euphausia superba recovered and hence provided evidence that krill is readily consumed by $A$. forsteri when encountered.

Previous investigations on the zooplankton of the shelf system of the Weddell Sea, although performed later in the season, found only small numbers of Euphausia superba in the plankton. The smaller E. crystallorophias was the dominant euphausiid (Siegel 1982; Hempel et al. 1983). Similarly, swarming krill in open water was the exception during the WWSP. However, large numbers were observed, by remote-controlled underwater video camera, inhabiting the corrugated underside of ice floes and feeding on epontic organisms (H.-P. Marschall, AWI für Polarforschung Bremerhaven, personal communication). This observation and the absence of $E$. crystallorophias in the diet samples suggests that most krill were consumed under the ice and not in open water. For the purpose of this discussion, Euphausia superba may be considered as an ice associated prey item.

Thus the prey of the emperor penguin in the eastern Weddell Sea consists of either midwater (fish, squid) or ice associated animals (krill) consistent with the partitioning of the diet samples into two main groups according to the dominant prey type (Fig. 1). In conclusion, the data suggest two different feeding strategies: deep dives during which relatively few but large fish and squid are consumed, and shallow dives exploring the rugged underside of sea ice where numerous but small krill are taken. Data on dive profiles of individual penguins would enable this hypothesis to be tested.

\section{Feeding Ecology}

Cracknell (1986) observed at the Amanda Bay colony that emperor penguins stopped passing his observation post during the four darkest hours of the night on 1 to 2 October. One-and-a-half months later and then with continuous daylight this phenomenon was not observed in the Drescher Inlet.

Feeding intervals of chicks estimated from daily weighings by Offredo and Ridoux (1986) were slightly longer than those in this study (1.8 days and 1.44 days, respectively). But mean mass of the stomach contents was higher ( $2820 \mathrm{~g}$ versus $1335 \mathrm{~g}$ ), more than compensating for the longer lapse between successive feeds.

Acknowledgements. My participation in the WWSP was funded by the South African Scientific Committee for Antarctic Research. The Alfred-Wegener-Institut für Polar- und Meeresforschung, West Germany, and its director G. Hempel provided generous logistical support as did J. Plötz in his untiring effort to organize the field work in the Drescher Inlet. D. Gerdes and R. Steinmetz helped wrestle with penguins, S. Klages measured numerous hard-prey remains, N. Adams and C. Brown commented on the manuscript. Their assistance is gratefully acknowledged.

\section{References}

Adams NJ (1987) Foraging range of king penguins Aptenodytes patagonicus during summer at Marion Island. J Zool London $212: 475-482$

Adams NJ, Klages N (1987) The diet of king penguin Aptenodytes patagonicus at sub-Antarctic Marion Island. $\mathrm{J}$ Zool London 212:303-324

Adams NJ, Klages N (in press) Diet of the gentoo penguin (Pygoscelis papua) at sub-Antarctic Marion Island. Colonial Waterbirds

Bowman TE, Gruner H-E (1973) The families and genera of Hyperiidea (Crustacea, Amphipoda). Smithson Contrib Zool 146:1-64

Brown CR, Klages N (1987) Seasonal and annual variation in diets of southern rockhopper (Eudyptes chrysocome chrysocome) and macaroni penguin (E. chrysolophus) at sub-Antarctic Marion Island. J Zool London 212:7-28

Clarke MR (1962) The identification of cephaloped "beaks" and the relationship between beak size and total body weight. Bull $\mathrm{Br}$ Mus Nat Hist 8:419-480

Clarke MR (1986) A handbook for the identification of cephalopod beaks. Clarendon, Oxford, $273 \mathrm{pp}$

Cracknell GS (1986) Population counts and observations at the emperor penguin (Aptenodytes forsteri) colony at Amanda Bay, Antarctica. Emu 86:113-117

Duffy DC, Jackson S (1986) Diet studies of seabirds: a review of methods: Colon Waterbirds 9:1-17

Fischer W, Hureau JC (1985) FAO species identification sheets for fishery purposes. Southern Ocean. FAO 2:233-470

Filipova YA (1972) New data on the squids (Cephalopoda, Oegopsida) from the Scotia sea. Malacologia 11:391-406

Green K (1986) Food of the emperor penguin Aptenodytes forsteri on the Antarctic fast ice edge in late winter and early spring. Polar Biol $6: 187-188$

Hempel I, Hubold G, Kaczmaruk B, Keller R, Weigmann-Haas R (1983) Distribution of some groups of zooplankton in the inner Weddell Sea in summer 1979/80. Ber Polarforsch 12:1-34

Hecht T (1987) A guide to the otoliths of Southern Ocean fishes. S Afr J Antarct Res 17:2-87

Hubold G (1984) Spatial distribution of Pleuragramma antarcticum (Pisces: Nototheniidae) near the Filchner- and Larsen Ice Shelves (Weddell Sea, Antarctica). Polar Biol 3:231-236

Hubold G (1985) Stomach contents of Antarctic silverfish Pleuragramma antarcticum from the southern and eastern Weddell Sea. Polar Biol 5:43-48

Hyslop EJ (1980) Stomach content analysis - a review of methods and their application. J Fish Biol 17:411-429

Kils U (1981) Swimming behaviour, swimming performance and energy balance of Antarctic krill Euphausia superba. Biomass Sci Ser 3:122 pp

Kirkwood J (1982) A guide to the Euphausiacea of the Southern Ocean. ANARE Res Notes 1:1-45

Klages N, Gerdes D (1988) A little known colony of emperor penguins on the coast of the eastern Weddell Sea. S Afr J Antarct Res $18: 18-20$ 
Kooyman GL (1981) Weddell seal Leptonychotes weddelli. In: Ridgeway SHR, Harrison RJ (eds) Handbook of marine mammals. Academic Press, London, pp 275-296

Kooyman GL, Drabeck CM, Elsner R, Cambell WB (1971) Diving behaviour of the emperor penguin Aptenodytes forsteri. Auk 88:775-795

Levick GM (1914) Antarctic penguins. Heinemann, London, $140 \mathrm{pp}$

Murphy RC (1936) Oceanic birds of South America. Mac Millan, New York

Nemoto T, Okiyama M, Takahashi M (1985) Aspects of rôles of squid in food chains of marine Antarctic ecosystems. In: Siegfried WR, Condy PR, Laws RM (eds) Antarctic nutrient cycles and food webs. Springer, Berlin Heidelberg, pp 415-420

Offredo C, Ridoux V (1986) The diet of emperor penguins Aptenodytes forsteri in Adélie Land, Antarctica. Ibis 128:409-413

Offredo C, Ridoux V, Clarke MR (1985) Cephalopods in the diet of emperor and Adélie penguins in Adélie Land, Antarctica. Mar Biol 86:199-202

Okutani T, Clarke MR (1985) Identification key and species description for Antarctic squids. Biomass Handb 21:57 pp
Plötz J (1986) Summer diet of Weddell seals (Leptonychotes weddelli) in the eastern and southern Weddell Sea, Antarctica. Polar Biol 6:97-102

Prevost J, Sapin-Jaloustre J (1965) Ecologie des manchots antarctiques. In: Mieghem $\mathbf{J}$ van, Oye $P$ van (eds) Biogeography and ecology in Antarctica. Junk Publ, The Hague, pp 551-648

Rodhouse PG, Clarke MR (1986) Distribution of the early-life phase of the Antarctic squid Galiteuthis glacialis in relation to the hydrology of the Southern Ocean in the sector $15^{\circ}$ to $30^{\circ} \mathrm{E}$. Mar Biol 91:353-357

Siegel V (1982) Investigations on krill Euphausia superba in the southern Weddell Sea. Meeresforschung 29:244-252

Stonehouse B (1953) The emperor penguin Aptenodytes forsteri. 1. Breeding behaviour and development. FIDS Sci Rep 6:1-33

Stonehouse B (1967) The general biology and thermal balances of penguins. Adv Ecol Res 4:131-196

Wilson RP (1984) An improved stomach pump for penguins and other seabirds. J Field Ornithol 55:109-112 